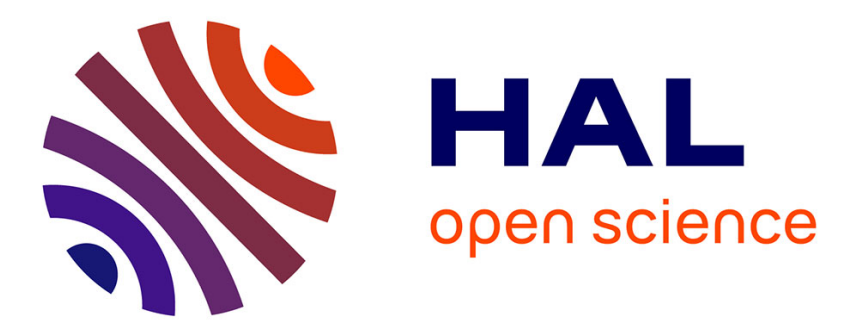

\title{
Dual function of Lectins - new perspectives in targeted Photodynamic therapy
}

\author{
Vanya Bogoeva, Lidiya Petrova, Anna Yordanova, Julie Bouckaert, Ivan \\ Ivanov, Régis Vanderesse, Céline Frochot
}

\section{To cite this version:}

Vanya Bogoeva, Lidiya Petrova, Anna Yordanova, Julie Bouckaert, Ivan Ivanov, et al.. Dual function of Lectins - new perspectives in targeted Photodynamic therapy. Journal of Porphyrins and Phthalocyanines, 2019, 23 (11), pp.1241 - 1250. 10.1142/S1088424619300209 . hal-02382103

\section{HAL Id: hal-02382103 \\ https://hal.univ-lorraine.fr/hal-02382103}

Submitted on 17 Nov 2020

HAL is a multi-disciplinary open access archive for the deposit and dissemination of scientific research documents, whether they are published or not. The documents may come from teaching and research institutions in France or abroad, or from public or private research centers.
L'archive ouverte pluridisciplinaire HAL, est destinée au dépôt et à la diffusion de documents scientifiques de niveau recherche, publiés ou non, émanant des établissements d'enseignement et de recherche français ou étrangers, des laboratoires publics ou privés.

\section{(c)(1)}

Distributed under a Creative Commons Attribution| 4.0 International License 


\title{
Dual function of Lectins - new perspectives in targeted Photodynamic therapy.
}

\author{
Vanya Bogoeva ${ }^{\star a}$, Lidiya Petrova ${ }^{b}$, Julie Bouckaert ${ }^{c}$, AnnaYordanova $^{a}$, Ivan Ivanov ${ }^{d}$, \\ Régis Vanderesse ${ }^{\mathrm{e}}$, Céline Frochot ${ }^{\mathrm{f}}$
}

a Institute of Molecular Biology “Roumen Tsanev", Bulgarian Academy of Sciences, “Acad. G. Bonchev" Str. Bl. 21, 1113, Sofia, Bulgaria.

b Medical University of Pleven, Department of Anatomy, Histology, Cytology and Biology, 1 “Sv. Kliment Ohridski Str.”, 5800 Pleven, Bulgaria.

c Unité de Glycobiologie Structurale et Fonctionelle (UGSF), UMR 8576 of the University of Lille and CNRS, 50 Av. de Halley, Villeneuve d'Ascq 59658, France

d Institute of Catalysis, Bulgarian Academy of Sciences, “Acad. G. Bonchev" Str., 1113, Sofia, Bulgaria

e LCPM UMR 7375 CNRS-University of Lorraine, 1 rue Grandville, BP20451 54001 Nancy cedex, France.

fLRGP UMR 7274 CNRS-University of Lorraine, 1 rue Grandville, BP20451 54001 Nancy cedex, France.

Received date (to be automatically inserted after your manuscript is submitted)

Accepted date (to be automatically inserted after your manuscript is accepted)

\begin{abstract}
Porphyrins and phthalocyanines are photosensitizers (PS) that are used in clinical imaging, detection of cancer cells and are particularly applied in photodynamic therapy (PDT). Many scientists have been focused on the design of different porphyrin compounds. However, similar to other anti-cancer agents, they cannot recognize selectively tumor tissues. Scientists are seeking new decisions to overcome this problem and to find appropriate targeted delivery strategies. Plant lectins are especially suitable molecules for such targeting as they preferentially recognize specific antigens on the glycosylated cancer cells. This review will give more detailed information about the dual function of lectins and their interactions with PSs, which is a new perspective in targeted PDT. The implications and potential applications of such studies will also be discussed.
\end{abstract}

KEYWORDS: PDT, targeting, lectins

* Corresponding author: Prof. Vanya Bogoeva, Institute of Molecular Biology "Roumen Tsanev“ Bulgarian Academy of Sciences "Acad. G. Bonchev“ Str., B1. 21 1113, Sofia, Bulgaria. E-mail: vanya.bogoeva@gmail.com; Phone: +35902979 2638 


\section{WHY LECTINS ARE USEFUL TOOLS FOR THE TARGETED THERAPY?}

Many anticancer drugs cannot recognize selectively tumor tissues and cause destruction of normal tissues. Cisplatin is still one of the most applied chemotherapeutic drugs which is used to treat various types of cancers, including sarcomas, carcinomas, testicular, ovarian and other cancers [1-3]. However, the toxicity of cisplatin leads to strong side effects such as ototoxicity and nephrotoxicity which remain major issues in its clinical application [4,5]. These severe side effects are a result of the lack of selectivity of the drug for the tumor tissue and can induce acquired or intrinsic resistance.

A rational and innovative approach to improve the selective recognition of the drug is to incorporate an appropriate drug delivery molecule that recognizes membranar tumor receptor [6]. Considering this, many scientists focused their research on lectins (carbohydrate-binding proteins). Lectins are glycoproteins found in high concentration in most dry legume seeds (lentils, beans, peas), cereals, but also in nature (other families of plants, fungi and animals too).

Tumor cells are aberrantly glycosylated and that change in glycan coating of the cancerous cells can be selectively recognized by lectins [7].

Aberrant O-glycans that are expressed at the surface of cancer cells have been identified as glyco-markers for diagnosis and prognosis of cancer diseases. They consist of $\mathrm{T}$ and $\mathrm{Tn}$ antigens and Lewis a, Lewis $\mathrm{x}$ and Forssman antigens.

Comparing to monoclonal antibodies that are used as standard probes to detect O-glycosylation aberrations occuring at cancer cell surface, many lectins also possess flexibility in recognizing the O-glycans that make T/Tn -specific lectins suitable candidates for the selective targeting of tumor cells.

Some of these T/Tn-specific lectins are isolated from plants such as jacalin (from Artocarpus integrifola), Agaricus bisporus lectin from mushroom, etc.

Interestingly, these lectins can bind $\mathrm{T} / \mathrm{Tn}$ antigens within their specific monosaccharide-binding sites for which they are used as tools for cancer diagnosis, prognosis and therapy [8].

This specific lectin recognition to target tumor cells explains the ability of many plant lectins, including concanavalin A (ConA), Galanthus nivalis lectin, etc, to affect cellular processes such as apoptosis, autophagy, inflammation, etc.

On Table 1 is summarized and presented the cytotoxic and immunological effects of several lectins upon various malignant cells. This demonstrates their dual function targeting malignant tumor cells and inducing cell growth inhibition or to inducing an immune response [8].

Table 1. Effect of some plant lectins against tumor cells.

\begin{tabular}{|l|c|c|c|c|}
\hline \multicolumn{1}{|c|}{ Species } & Plant parts & Lectin & Cytotoxic activity & Ref. \\
\hline $\begin{array}{c}\text { Abelmoschus } \\
\text { esculentus }\end{array}$ & seeds & AEL & $\begin{array}{c}\text { AEL inhibits cell proliferation and induces } \\
\text { apoptosis in human breast cancer (MCF7) cells. }\end{array}$ & {$[9]$} \\
\hline $\begin{array}{c}\text { Agaricus } \\
\text { bisporus }\end{array}$ & mushroom & ABL & $\begin{array}{c}\text { ABL binds Tn antigen and inhibits proliferation } \\
\text { of human colorectal adenocarcinoma cell lines }\end{array}$ & {$[10,11]$} \\
\hline
\end{tabular}




\begin{tabular}{|c|c|c|c|c|}
\hline & & & (HT29, LS174T, SW1222). & \\
\hline $\begin{array}{l}\text { Amaranthus } \\
\text { caudatus }\end{array}$ & seeds & $\begin{array}{l}\text { ACL/ACA } \\
\text { Amaranthin }\end{array}$ & $\begin{array}{l}\text { ACL/ACA are T/Tn-specific amaranthin; ACL is } \\
\text { marker of cellular proliferation and progression of } \\
\text { malignant colon cancer in humans. }\end{array}$ & [12] \\
\hline $\begin{array}{l}\text { Amaranthus } \\
\text { viridis }\end{array}$ & seeds & AVL & $\begin{array}{l}\text { AVL demonstrates antiproliferative activity to } \\
\text { murine cancer cell lines (HB98 and P388D1). }\end{array}$ & [13] \\
\hline $\begin{array}{r}\text { Artocarpus } \\
\text { heterophyllus }\end{array}$ & seeds & Jacalin & $\begin{array}{l}\text { Jacalin inhibits the cellular growth of human } \\
\text { colon cancer cells, breast cancer (MCF7) and non- } \\
\text { small lung carcinoma cell lines (H1299). }\end{array}$ & {$[14,15]$} \\
\hline $\begin{array}{l}\text { Canavalia } \\
\text { brasiliensis }\end{array}$ & seeds & ConBr & $\begin{array}{l}\text { ConBr exhibits antiproliferative activity and } \\
\text { induces apoptosis in murine melanoma B16F10 } \\
\text { cells, human leukemia (MOLT-4) and (HT-60) } \\
\text { cells. }\end{array}$ & {$[16]$} \\
\hline $\begin{array}{l}\text { Canavalia } \\
\text { ensiformis }\end{array}$ & seeds & Con A & $\begin{array}{l}\text { ConA demonstrates cytotoxic effect to different } \\
\text { cancer cell lines (MOLT-4, HL-60, PU-1.8, A375), } \\
\text { fibroblasts, hepatoma (HepG2), glioblastoma (U87) } \\
\text { and p53-null cells causing apoptosis, autophagy and } \\
\text { anti-angiogenesis. ConA is used in clinical and pre- } \\
\text { clinical studies, as potential agent for cancer } \\
\text { therapy. }\end{array}$ & {$[16,17]$} \\
\hline $\begin{array}{l}\text { Euphorbia } \\
\text { tirucalli }\end{array}$ & branches & Eutirucallin & $\begin{array}{l}\text { Eutirucallin manifests antiproliferative effect to } \\
\text { various human cancer cell lines (HeLa, PC3, MDA- } \\
\text { MB-231, and MCF-7), in vivo inhibits the Ehrlich } \\
\text { ascites carcinoma. }\end{array}$ & {$[18]$} \\
\hline $\begin{array}{l}\text { Galanthus } \\
\text { nivalis (GNA); } \\
\text { Hippeastrum } \\
\text { hybrid } \\
\text { (Amaryllis) } \\
\text { (HHA) }\end{array}$ & bulbs & $\begin{array}{l}\text { GNA } \\
\text { HHA }\end{array}$ & $\begin{array}{l}\text { GNA and HHA selectively inhibit human } \\
\text { immunodeficiency virus type } 1 \text { (HIV-1) and HIV-2 } \\
\text { strains, as inhibiting infection of T lymphocytes. }\end{array}$ & [19] \\
\hline $\begin{array}{l}\text { Lotus } \\
\text { corniculatus }\end{array}$ & seeds & LCL & $\begin{array}{l}\text { LCL shows a strong antiproliferative effect on } \\
\text { human leukemic (THP-1), lung cancer (HOP62) } \\
\text { and colon cancer (HCT116) cell lines. }\end{array}$ & [20] \\
\hline $\begin{array}{l}\text { Moringa } \\
\text { oleifera }\end{array}$ & seeds & cMoL & $\begin{array}{l}\text { cMoL causes cytotoxicity to murine melanoma } \\
\text { cells (B16-F10) and human peripheral blood } \\
\text { mononuclear cells as increasing mitochondrial ROS } \\
\text { and inducing apoptosis by caspase cascade. }\end{array}$ & {$[21,22]$} \\
\hline
\end{tabular}




\begin{tabular}{|c|c|c|c|c|}
\hline & & WSMoL & $\begin{array}{l}\text { Both lectins: cMoL and WSMoL exhibit } \\
\text { low/moderate cytotoxicity to human pulmonary } \\
\text { mucoepidermoid carcinoma (NCI-H292), human } \\
\text { colon adenocarcinoma (HT-29) and human larynx } \\
\text { epidermoid carcinoma (HEp-2) cells. }\end{array}$ & \\
\hline $\begin{array}{l}\text { Ricinus } \\
\text { communis }\end{array}$ & seeds & Ricin & $\begin{array}{l}\text { Ricin shows cytotoxicity towards cervical cancer } \\
\text { cells (Hela), sarcoma } 180 \text { ascites tumor cells, } \\
\text { hepatoma cells (BEL 7404). }\end{array}$ & {$[23,24]$} \\
\hline $\begin{array}{l}\text { Triticum } \\
\text { vulgaris }\end{array}$ & root & WGA & $\begin{array}{l}\text { WGA demonstrates cytotoxic effect in human } \\
\text { hepatoma (H3B), human choriocarcinoma (JAr), rat } \\
\text { osteosarcoma (ROS), human acute myeloid } \\
\text { leukemia (AML) cells. It induces apoptosis in } \\
\text { pancreatic cancer cells. WGA is a potential } \\
\text { candidate for leukemia therapy. }\end{array}$ & [25-27] \\
\hline $\begin{array}{l}\text { Viscum } \\
\text { album }\end{array}$ & seeds & $\begin{array}{l}\text { ML-I; } \\
\text { ML-II; } \\
\text { ML-III }\end{array}$ & $\begin{array}{l}\text { It shows cytotoxicy towards human acute } \\
\text { lymphoblastic leukemia (Molt 4) cells. }\end{array}$ & [28] \\
\hline
\end{tabular}

Recently, T/Tn specific lectins have been identified as potential targeting molecules [29]. The non-covalent binding of porphyrins to lectins was well studied [30, Bogoeva, $2010 \# 314$ ], particularly the interaction of wheat germ agglutinin (WGA) [31-34] and Con A with porphyrins was evaluated and affinity constants in micromolar range were calculated, accordingly $[35,36]$.

\section{PORPHYRINS - BRIEF OVERVIEW}

Porphyrins are a group of intensely colored compounds related to natural products as hemoglobin, myoglobin, chlorophyll, etc. These chemical compounds play role in biologically important processes, such as: photosynthesis, transport of oxygen, etc. However, their low solubility led to the development of new compounds conferring improved properties in terms of toxicology, uptake and better stability under physiological conditions. Malik and Jaldetti evidenced in 1980 that protoporphyrin IX alone and without irradiation could induce inhibition of RNA and DNA synthesis (even if the light improved considerably this inhibition) [37]. Lottner et al. [38,39] combined the cytotoxic effects of cisplatin analogues linked to pegylated hematoporphyrins. They described the synthesis and properties of some hematoporphyrin-platinum conjugates and observed a synergistic cooperation on TCC-SUP bladder cancer cells. Kim et al. obtained a similar result on leukemia L1210 cell line $[6,40]$. Such constructs have also been obtained with ruthenium tetracarbonyl complexes grafted at meso position(s) of free base or Zinc (II) porphyrins [41,42].

Moreover, Ando et al. showed that tri and tetravalent metal (Ga, In, Sn, Mn and Fe) 2,4-bis(1-decyloxyethyl)porphyrinyl-6,7-bisaspartic acid showed an increased cytotoxicity compared to the free or the divalent metal porphyrins ( $\mathrm{Zn}, \mathrm{Cu}$ and $\mathrm{Ni}$ ) [43]. Che's group [44] made the same observation with a series of gold(III) meso-tetraarylporphyrins which induced p53-dependent apoptosis of several cancer cell lines (KB-3-1, HL-60, HepG2, SUNE1, HeLa, KB-V1, CNE1). 
They showed that gold(III) meso-tetraarylporphyrin chloride exhibited a 30-fold higher cytotoxicity compared to cisplatin [45,46]. In 2010, the same group [47] described 5-hydroxyphenyl analogous with improved solubility and aqueous stability, and which appeared to be 100 to 3,000-fold more cytotoxic for MDA-MB-231 cells than the cisdiamminedichloroplatinum(II). For the live mice, the average tumour weights were $66 \%$ lower compared to untreated animals. Liu et al. described 5-[4-(4-ethoxycarbonylbutoxy)phenyl]-10,15,20-tri(4methoxyphenyl)porphyrinatgold(III) chloride and evaluated an $\mathrm{IC}_{50}$ value of only $29 \mu \mathrm{M}$ against SGC-7901 human gastric cancer cells [48].

Like platinum complexes, "central"-ruthenium complexes have been also investigated and Tanaka's group designed dioxoruthenium(VI) tetraphenylporphyrins on which ursene-type pentacyclic triterpenes were grafted at one of the mesopositions [49].

\section{PHOTOSENSITIZERS AS PDT AGENTS}

PSs are particularly attractive for their clinical applications, especially in PDT.

PDT appears as an innovative technology being investigated to fulfill the need for a targeted cancer treatment that may reduce recurrence and extend survival with minimal side effects [50]. PDT aims at selectively killing neoplasic lesions by the combined action of a PS and visible light whose combined action mainly results in the formation of reactive oxygen species (ROS) especially singlet oxygen $\left({ }^{1} \mathrm{O}_{2}\right)$, thought to be the main mediator of cellular death induced by PDT. Destruction of the vasculature may indirectly lead to tumor eradication, following deprivation of life-sustaining nutrients and oxygen [51,52], and this effect is thought to play a major part in the destruction of some tumors by PDT [53-57].

The same treatment can also be applied for the destruction of pathogenic bacteria in infection biology. Verteporfin has been used for the delivery of ampicillin and photodynamic destruction of uropathogenic E. coli [58].

The successful PDT widely depends on the nature of the PSs, which are able to absorb light of specific wavelength and transform it into energy, which can generate ROS in the presence of molecular oxygen (Fig. 1), an appropriate dosimetry and the presence of oxygen.

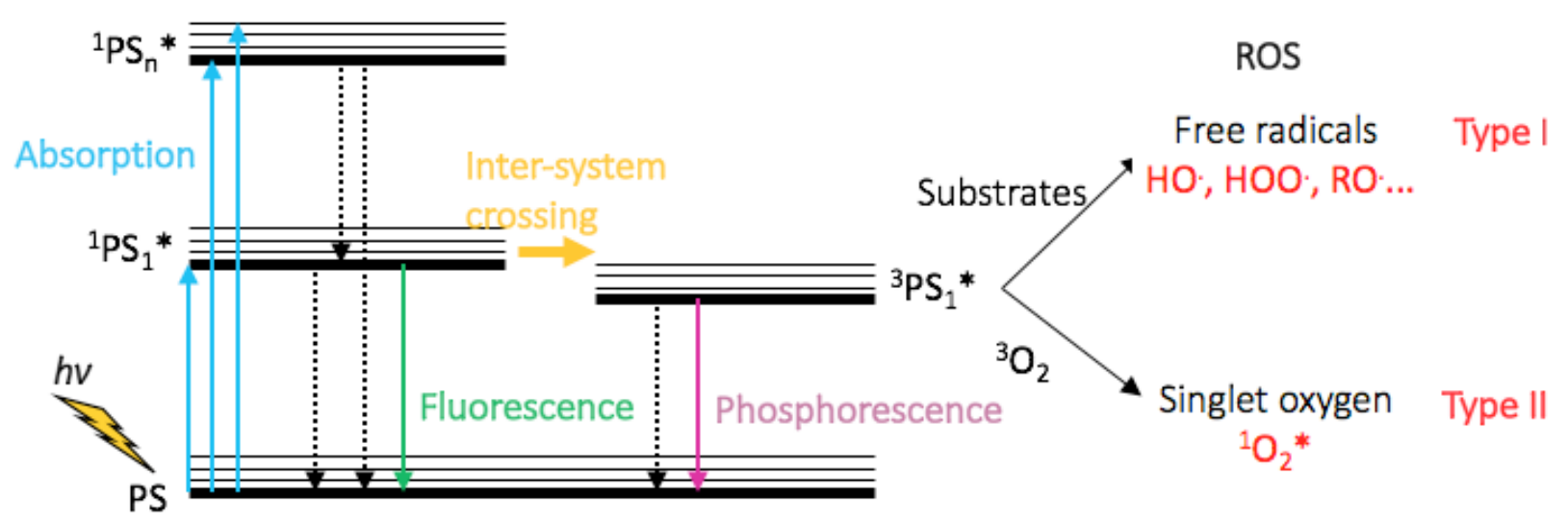

Fig. 1. Jablonski's energy level diagram for photodynamic therapy.

The pathways of energy dissipation after light absorption of a molecule can be described with the help of Jablonskidiagram (Fig. 1). The first step of photosensitizing mechanism is the absorption of a light energy (hv) by the PS, that leads 
to the electronic excitation of PS from its ground state $\left({ }^{1} \mathrm{PS}_{0}\right)$ to the unstable excited singlet state $\left({ }^{1} \mathrm{PS}_{1}{ }^{*}\right)$ and also to higher electronic state energy $\left({ }^{1} \mathrm{PS}_{2}{ }^{*},{ }^{1} \mathrm{PS}_{3}{ }^{*}, \ldots{ }^{1} \mathrm{PS}_{\mathrm{n}}{ }^{*}\right)$. This excited singlet state has a very short half-life which is in the range of $10^{-6}$ to $10^{-9} \mathrm{~s}$. Through a series of vibrational relaxation (internal conversion), the excited PS either decays back to the excited state of the lowest energy level $\left({ }^{1} \mathrm{PS}_{1}{ }^{*}\right)$ or to the ground state, resulting in the fluorescence emission and/or nonradiative deactivation processes. The excited PS which is converted back to the initial ground state can subsequently absorb another photon to begin the cycle again. Some of the excited PS at the single state may also undergoes intersystem crossing (ISC) to the excited triplet state $\left({ }^{3} \mathrm{PS}_{1}{ }^{*}\right)$, which is a longer-lived species $\left(10^{-3} \mathrm{~s}\right)$.

The excited ${ }^{3} \mathrm{PS}_{1} *$ may also return back to the ground state by emitting phosphorescence. The interaction of the ${ }^{3} \mathrm{PS}_{1}{ }^{*}$ with the surrounding molecules resulted in mainly two types of photo-oxidative reaction, either by an electron transfer or hydrogen transfer process (Type I reaction) or by an energy transfer reaction with oxygen (Type II reaction).

In biological systems, the generated ROS triggers a cascade of biochemical effects that result in cell death.

Among the most used PSs in PDT, porphyrins play a role of choice because of their intrinsic characteristics and their relatively easy synthesis. The first syntheses of porphyrin were performed by Rothemund from pyrrole and benzaldehyde in 1940s [59] and improved by Lindsey et al. [60,61].

The method of Adler-Longo, thanks to milder reaction conditions, allowed the use of a greater variety of aldehydes, and therefore the synthesis of a wide variety of symmetrical meso-tétraarylporphyrines [62]. In 1975, Little adopted this method to the synthesis of unsymmetrical meso-arylporphyrines. This "mixed aldehydes" synthesis involves a pyrrole and two different aldehydes in propionic acid under reflux [63]. Many improvements have been made like the synthesis on solid support [64], the use of microwave irradiation [65-68] or the use of building blocks (syntheses $2+2$ [69-71] or $3+1$ [7274]).

\section{'Passive' and 'active' targeting}

The mechanism of targeting can be divided into 'passive' and 'active' targeting. Passive targeting is the promotion of drug access into the tumour cells by physicochemical factors of drug carrier (i.e. material composition, size and surface properties) and by pathological factors of the organism (i.e. tumour microenvironment and enhanced permeability and retention effect (EPR effect)). The passive targeting may result from greater proliferative rates of neoplastic cells, poorer lymphatic drainage, vascular leakage or specific interaction between PS and neoplastic cells due to the charge, size, and structure of the PS. However, the passive targeting of tumour cells in PDT involves the vector of PSs with different formulation systems to facilitate their transport and incorporation into cancer cells. [75]. Several types of vectors can be used such as liposomes, nanoparticles as well as emulsion and micellar systems.

Active targeting involves delivery of drug to the target sites based on molecular recognition, using the specific ligands which bind to appropriate receptors, overexpressed at the target site [76,77].

Targeting ligands are designed specifically to bind to receptors, overexpressed only by tumour cells or tumour vasculature and should be expressed homogenously on all targeted cells. The mechanisms that cause tumour eradication by targeting the specific site are named direct and indirect effect. Direct effect involves the destruction of tumour cells by necrosis and apoptosis, while indirect effect refers to the destruction of tumour vasculature that further caused inflammatory and immunity responses to the host system. The relative contribution of each effect depends on: (1) the type of tumour, (2) the nature of the PS, and (3) PDT conditions used (i.e. the time delay of irradiation after PS administration, fluence) $[78,79]$. 
The direct active targeting of internalization-prone cell-surface receptors in PDT, overexpressed by cancer cells is to improve the cellular uptake of PSs or PSs-vector systems in combination with the molecules with high affinity for specific markers of tumour cells. Some examples of the PSs or PSs-vector systems targeting the internalization-prone receptors in PDT are the growth factor receptors [80,81], the low density lipoproteins (LDL) receptors [82-84], the transferrin receptors [85-88], the folate receptors [89-91]; , the glucose transporters [92-94]\}, the lectins [95] and the insulin receptors [96].

Concerning the indirect effect of active targeting, the vascular targeted PDT or known as VTP is based on the targeting of PSs towards the tumour neovascularization. Targeting molecules can be peptides, antibodies or other ligands specifically recognizing the proteins overexpressed in neo-vessels [97]. Many markers of tumour vasculature have been identified for endothelial cells (i.e. VEGFR-2, NRP-1, $\alpha_{\mathrm{v}} \beta 3$ integrin), pericytes, platelet-derived growth factor receptor- $\beta$ (PDGFR- $\beta$ ), high-molecular-weight melanoma-associated antigen NG2) and basement membranes (i.e. laminin, fibronectin, collagen IV). The main targets of the tumoural endothelium are; the VEGF, the $\alpha_{\mathrm{v}} \beta_{3}$ integrin and the tissue receptor factor. As an example, the PDT team in Nancy designed a chlorin to a heptapeptide (ATWLPPR) and pentapeptides (DKPPR and TKPRR), specific for neuropilin-1 receptor (NRP-1) [98-103].

\section{LECTINS AS POTENTIAL PS CARRIER MOLECULES}

\section{Non-covalent binding of Ps to lectins.}

Due to the application of porphyrins as PSs in PDT to treat cancer, and the ability of many lectins to recognize tumor cells, studies on the interaction of porphyrins with lectins are of considerable interest.

Several scientists hypothesized in early 1988 that the targeting portion of some lectin molecules might be used to bind PSs.

This appears to be useful in order to increase the selective accumulation of porphyrin-based drugs to tumours.

Relating to this Bhanu et al. [104] in 1997 studied the interaction of a free base porphyrin, mesotetrasulphonatophenylporiphyrin and the corresponding metal derivative, meso-zinc-tetrasulphonatophenylporphyrin with two legume lectins, concanavalin A and pea (Pisum sativum) lectin. It was found that both free lectin and lectin saturated with the specific saccharide bind the porphyrin with comparable binding strength.

Similar results were obtained for the interaction of several free-base porphyrins and their corresponding copper(II) and zinc(II) derivatives with the galactose-specific lectin from snake gourd (Trichosanthes anguina) seeds. [105].

The binding of several metallo-porphyrins meso-tetra(4-sulphonatophenyl)porphyrinato copper(II) (CuTPPS), and mesotetra(4-methylpyridinium)porphyrinato copper(II) (CuTMPyP) with the galactose-specific lectin from Trichosanthes cucumerina (TCSL) has also been investigated. The dimeric lectin bound two porphyrin molecules and the presence of the specific saccharide lactose did not affect porphyrin binding. The thermodynamic study showed that porphyrin binding to TCSL was mainly driven by the change in entropy, while the enthalpic contribution was very small. [106].

The interaction of several free-base and metalloporphyrins with Momordica charantia (bitter gourd) lectin (MCL) was investigated by absorption spectroscopy. The tetrameric MCL bound four porphyrin molecules, and the stoichiometry was unaffected by the presence of the specific sugar, lactose. Interestingly, both cationic and anionic porphyrins bound to the lectin with comparable affinity $\mathrm{K}_{\mathrm{a}}=10^{3}-10^{5} \mathrm{M}^{-1}$. Analysis of CD spectra of the protein indicated that binding of porphyrins does not significantly alter the secondary and tertiary structures of MCL [107]. 
Thermodynamic studies on the interaction of several free-base and metallo-porphyrins with pea (Pisum sativum) lectin (PSL) were also performed. Cationic and anionic porphyrins were found to bind to PSL with comparable affinity.[108].

The interaction of several free base porphyrins and their metal derivatives with jacalin was also-investigated by spectroscopy. This study showed that the binding of free lectin and lectin saturated with the specific saccharide bound different porphyrins. Binding of both anionic and cationic porphyrins were found to interact with the lectin with comparable affinity, indicated that the charge on the porphyrin did not play any role in the binding process and presumably the interaction was mediated by hydrophobic forces. It was well studied that jacalin (Artocarpus integrifolia agglutinin) specifically recognized the tumor-associated T-antigen disaccharide structure, which suggested about potential application of jacalin-porphyrin complexes in the targeted PDT [109].

All these investigations put forward a new direction of plant lectin research showing a new feature of lectins and presuming an idea of existence of a potential drug-porphyrin binding sites.

Carbohydrate binding property has been considered as the major property of all plant lectins for many decades. Studies carried out demonstrated that many plant lectins showed specific interactions with hydrophobic ligands. Such interactions appeared to be at specific sites that did not interfere with the ability of the lectins to bind carbohydrates. Porphyrins show binding affinities comparable to those for binding of carbohydrates to the lectins. Since lectins possess ability to specifically recognise the cell glycocode and can differentiate between healthy and malignant tissues, this reveal new direction in lectin research. It is considered to be related to their carbohydrate binding sites and newly definied "drug carrying sites", which was supposed to find appropriate application in targeted PDT. [108,110]

However, crystalographic studies have clearly demonstated the presence of the binding sites of lectins for porphyrins . It was found that the lectin peanut agglutinin (tetramer) binds meso-tetrasulfonatophenylporphyrin (H(2)TPPS). Crystallographic data have shown presence of specific lectin sites which can bind the porphyrins. There are distinguished three different binding sites for concanavalin A, peanut agglutininin and jacalin. In contrary to spectroscopic and thermodynamic data, some authors found that they bound in, over or near the carbohydrate binding sites (Fig. 2).

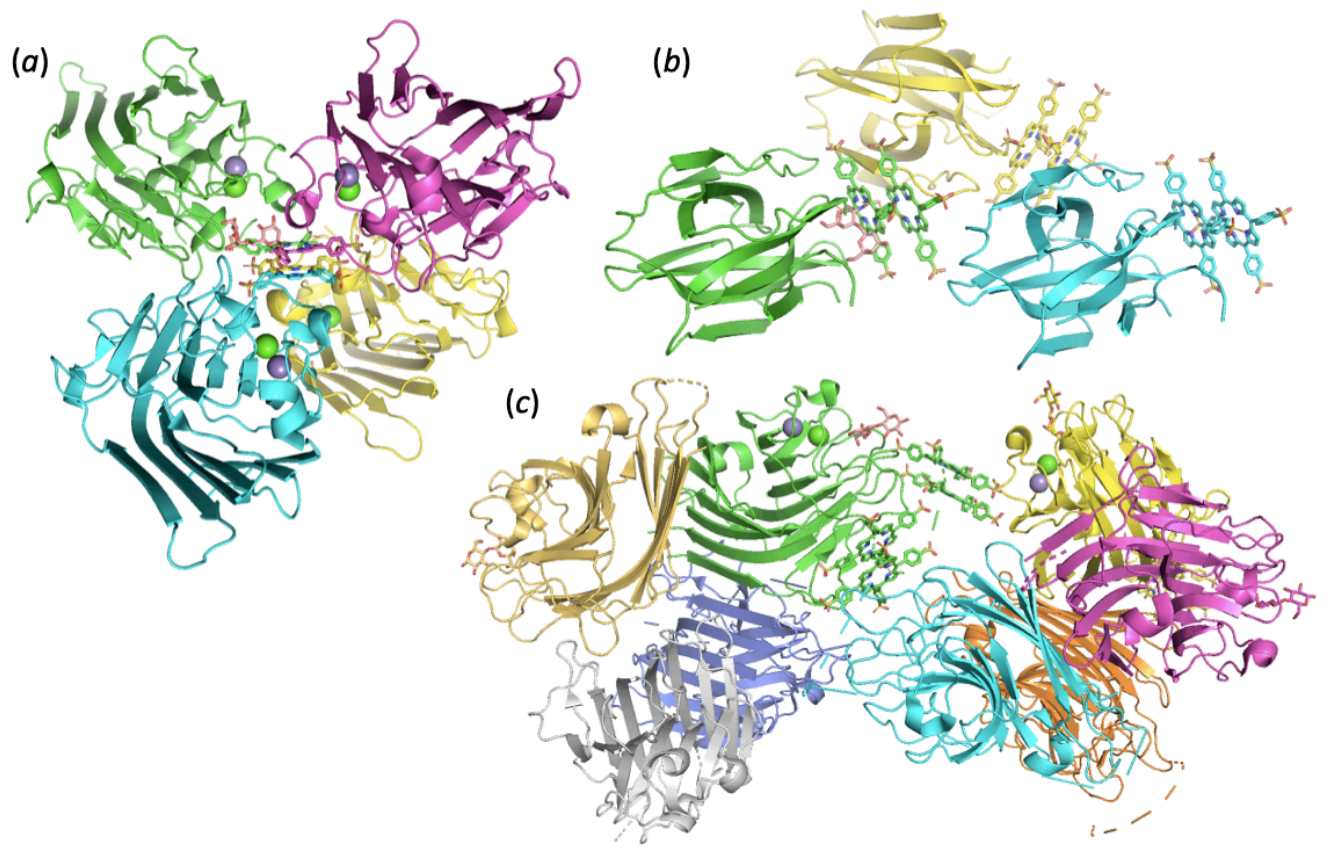


Fig. 2. Plant lectins associated into novel protein assemblies by H(2)TTPS: concanavalin A (PDB entry code 1JN2) (a), jacalin (PDB entry code 1PXD) (b) and peanut agglutinin (PDB entry code 1RIT) (c): stacked sandwiches of H(2)TTPS can be seen forming the crystal packing contacts. H(2)TTPS is shown in ball-and-stick in the same colour as their nearest lectin monomer, shown as a cartoon, to which they are bound. The transition metal ion is shown as a grey sphere, the calcium ion as a green sphere. The salmon-coloured dissacharide: respectvely Man- $\alpha 1$,6-Man (a), T-antigen (Gal $\beta 1-3 \mathrm{GalNAc})(b)$ and lactose (Gal- $\beta 1-4-\mathrm{GlcNAc}$ ), are not bound but are merely shown to indicate where the disaccharide binds in the absence of H(2)TTPS. It can be seen that H(2)TTPS binds in $(a)$, over $(b)$ or near $(c)$ the carbohydrate binding site of the lectins. (Figures created using Pymol)

Figure 2 presents 3 binding sites of porphyrins to concanavalin A (PDB 1JN2) [111], peanut agglutininin (PDB 1RIT) [112], and jacalin (1PXD) [113]. Interestingly, the porphyrin systematically binds near the carbohydrate-binding site, and prevents the binding of the sugar, but it does this in three different ways: mimicking the binding of mannose hydroxyl groups by the sulfonate oxygens (a), by hoovering above the binding site $(b)$ and allosterically (c). The carbohydratebinding sites project outwards at the four edges of each of these lectin oligomers and has a high tendency to serve as crystal packing contacts. In the crystal of the lectin-porphyrin complex, the H(2)TTPS maps unsaturated protein-carbohydrate interaction sites and generates thereby novel protein assemblies that differ from the tetrameric bioassembly, similar to what was observed following mutation of a carbohydrate-binding surface residue in the bacterial lectin FimH [114], [115]. The stabilizing effect of these newly-formed complexes is suggested by the fact that they can be crystallized into protein crystal that diffract at high resolution, and by the great definition of the H(2)TTPS molecules in their electron density. Such strong and stabilizing assemblies of PSs with the oligomeric lectins implies that lectins can function as PS carriers and amplify the reaction by means of their multivalent organisation and selective recognition of (tumour-associated) carbohydrate antigens.

\section{Covalent binding of PSs to Lectins.}

It is established that $\mathrm{Tn} / \mathrm{T}$-specific lectins are appropriate targeting molecules for improving the selectivity of PS. This enabled to improve both the stability of the lectin-Ps complex and the efficacy to destroy cancer cells.

Aiming this, Poiroux's group covalently linked the porphyrin (TrMPyP) to the plant lectin (Morniga G), known to recognize with high affinity tumor associated T/Tn antigen. They proved for the first time that, conjugation with plant lectins could be applied for targeting PSs towards Jurkat leukemia cells, e.g. to kill leukemia cells from blood and to preserve the normal leukocytes in extra corporeal photochemotherapy [116,117]. A comparative study of the toxicity of the different PSs targeted by the lectin Morniga $G$ was performed . It revealed that Al (III)-phthalocyanin-Morniga $G$ conjugate was a promising drug delivery molecule with $\mathrm{LD}_{50}=4 \mathrm{nM}$ preferentially destroying cancerous lymphocytes [118].

Jacalin was also used to target cancer Thomson Friedenreich antigen (Galß1-3GalNAc) [119].

\section{Lectin-phthalocyanine gold nanoparticles conjugate}

Obaid et al. (2012, 2015), directly coupled the jacalin lectin to gold nanoparticles linked to phthalocyanine to target the T antigen expressed on HT-29 colon adenocarcinoma cells $[119,120]$. They showed that jacalin targeting enhanced the cellular uptake of the nanoparticles. As a result of this, an enhanced PDT efficacy was observed after the light activation of jacalin nanoparticle conjugates, showing destruction of colon cancer cells. The paper highlighted that jacalin-PEG phthalocyanine nanoparticles demonstrated selectivity to target T-antigen, overexpressed on the surface of cancer cells 
eliciting PDT efficacy. This was procedeed by the previous finding of Yu [121], who reported that jacalin bound specifically the T antigen, expressed on cell surface of HT-29 cells with a dissociation constant of $500 \pm 50 \mathrm{nM}$.

\section{In conclusion}

Plant lectins are especially suitable for targeted PDT, as they preferentially recognize specific antigens on the glycosylated cancer cells. Therefore, they possess dual function to target tumor cells and to deliver selectively porphirins for the site of interests. This reveals new perspectives in biomedical application of plant lectins, especially in PDT.

\section{Acknowledgement:}

We are grateful to the National Fund for the joint French-Bulgarian project, DNTS 01/3 and the RILA Program Hubert Curien project (project code $38675 \mathrm{VG}$ ) for scientific exchange.

\section{REFERENCES}

1. Hambley TW. Coord. Chem. Rev. 1997; 166: 181-223.

2. Pratt WB, Ruddon RW, Ensminger WD and Maybaum J. The Anticancer Drugs (2nd edn.); Oxford University Press: New York, 1994; p 133.

3. Wong E and Giandomenico CM. Chem. Rev. 1999; 99: 2451-2466.

4. Ndagi U, Mhlongo N and Soliman ME. Drug. Des. Devel. Ther. 2017; 11: 599-616.

5. Von Hoff DD, Schilsky R, Reichert CM, Reddick RL, Rozencweig M, Young RC and Muggia FM. Cancer Treat. Rep. 1979; 63: 1527-1531.

6. Kim YS, Song R, Kim DH, Jun MJ and Sohn YS. Biorg. Med. Chem. 2003; 11: 1753-1760.

7. Lam SK and Ng TB. Appl. Microbiol. Biotechnol. 2011; 89: 45-55.

8. Cell Death \& DiseaseWang Y, Nangia-Makker P, Balan V, Hogan V and Raz A. Cell Death Dis. 2010; 1: Article e101.

9. Monte LG, Santi-Gadelha T, Reis LB, Braganhol E, Prietsch RF, Dellagostin OA, RR EL, Gadelha CA, Conceicao FR and Pinto LS. Biotechnol. Lett. 2014; 36: 461-469.

10. Jordinson M, El-Hariry I, Calnan D, Calam J and Pignatelli M. Gut 1999; 44: 709-714.

11. Yu L, Fernig DG, Smith JA, Milton JD and Rhodes JM. Cancer Res. 1993; 53: 4627-4632.

12. Atillasoy EO, Kapetanakis A, Itzkowitz SH and Holt PR. Mt. Sinai J. Med. 1998; 65: 146-153.

13. Kaur N, Dhuna V, Kamboj SS, Agrewala JN and Singh J. Protein Pept. Lett. 2006; 13: 897-905.

14. Geraldino TH, Modiano P, Veronez LC, Fl, \#xf3, ria-Santos M, Garcia SB and Pereira-da-Silva G. BioMed Res. Int. 2017; 2017: Article ID 4614357.

15. Zuraidah MA, Mimi Sakinah AM and Wan Azizi WS. JOLST 2014; 2: 55-59.

16. Faheina-Martins GV, da Silveira AL, Cavalcanti BC, Ramos MV, Moraes MO, Pessoa C and Araújo DAM. Toxicol. In Vitro 2012; 26: 1161-1169.

17. Li WW, Yu JY, Xu HL and Bao JK. Biochem. Biophys. Res. Commun. 2011; 414: 282-286. 
18. Palharini JG, Richter AC, Silva MF, Ferreira FB, Pirovani CP, Naves KSC, Goulart VA, Mineo TWP, Silva MJB and Santiago FM. Frontiers in Cellular and Infection Microbiology 2017; 7: 1-13.

19. Balzarini J, Hatse S, Vermeire K, Princen K, Aquaro S, Perno CF, De Clercq E, Egberink H, Vanden Mooter G, Peumans W, Van Damme E and Schols D. Antimicrob. Agents Chemother. 2004; 48: 3858-3870.

20. Rafiq S, Majeed R, Qazi AK, Ganai BA, Wani I, Rakhshanda S, Qurishi Y, Sharma PR, Hamid A, Masood A and Hamid R. Phytomedicine 2013; 21: 30-38.

21. Araujo LC, Aguiar JS, Napoleao TH, Mota FV, Barros AL, Moura MC, Coriolano MC, Coelho LC, Silva TG and Paiva PM. PLoS ONE 2013; 8: e81973.

22. de Andrade Luz L, Rossato FA, Costa R, Napoleao TH, Paiva PMG and Coelho L. Toxicol. In Vitro 2017; 44: 94-99.

23. Hu R, Zhai Q, Liu W and Liu X. J. Cell. Biochem. 2001; 81: 583-593.

24. Oda T, Aizono Y and Funatsu G. J. Biochem. 1984; 96: 377-384.

25. Ryva B, Zhang K, Asthana A, Wong D, Vicioso Y and Parameswaran R. Front. Oncol. 2019; 9: 1-13.

26. Schwarz RE, Wojciechowicz DC, Picon AI, Schwarz MA and Paty PB. Br. J. Cancer 1999; 80: $1754-1762$.

27. Wang H, Ng TB, Ooi VE and Liu WK. Int. J. Biochem. Cell Biol. 2000; 32: 365-372.

28. Frantz M, Jung ML, Ribereau-Gayon G and Anton R. Arzneimittelforschung. 2000; 50: 471-478.

29. Jiang QL, Zhang S, Tian M, Zhang SY, Xie T, Chen DY, Chen YJ, He J, Liu J, Ouyang L and Jiang X. Cell Prolif. 2015; 48: 17-28.

30. D’Auria S, Petrova L, John C, Russev G, Varriale A and Bogoeva V. Mol. Biosyst. 2009; 5: 1331-1336.

31. Bogoeva V, Petrova L, Ivanov I, Kulina H and Russev G. Biotechnol. Biotec. Eq. 2011; 25: $2519-2521$.

32. Bogoeva VP, Petrova LP, Ivanov IB, Kulina HN and Buchvarov IC. Mol. Biosyst. 2012; 8: $2633-2636$.

33. Bogoeva VP, Varriale A, Ivanov I, John CM and D'Auria S. C. R. Acad. Bulg. Sci. 2014; 67: 715-720.

34. Petrova L, Kulina H, Trifonov A, Russev G, Marinova K and Bogoeva V. Biotechnol. Biotec. Eq. 2013; 27: 38573860 .

35. Bogoeva V, Petrova L and Kubát P. J. Photochem. Photobiol. B: Biol. 2015; 153: 276-280.

36. Bogoeva VP, Petrova LP and Trifonov AA. Sci. Pharm. 2014; 82: 825-834.

37. Malik Z and Djaldetti M. Int. J. Cancer 1980; 26: 495-500.

38. Lottner C, Bart KC, Bernhardt G and Brunner H. J. Med. Chem. 2002; 45: 2064-2078.

39. Lottner C, Bart KC, Bernhardt G and Brunner H. J. Med. Chem. 2002; 45: 2079-2089.

40. Kim Y-S, Song R, Lee CO and Sohn YS. Bioorg. Med. Chem. Lett. 2004; 14: 2889-2892.

41. Johnpeter JP, Schmitt F, Denoyelle-Di-Muro E, Wagnieres G, Juillerat-Jeanneret L and Therrien B. Inorg. Chim. Acta 2012; 393: 246-251.

42. Schmitt F, Barry NPE, Juillerat-Jeanneret L and Therrien B. Bioorg. Med. Chem. Lett. 2012; 22: 178-180.

43. Ando T, Irie K, Koshimizu K, Takemura T, Nishino H, Iwashima A, Takeda N, Nakajima S and Sakata I. Photochem. Photobiol. 1993; 57: 629-633.

44. Che CM, Sun RWY, Yu WY, Ko CB, Zhu NY and Sun HZ. Chem. Commun. 2003: 1718-1719.

45. To YF, Sun RWY, Chen YX, Chan VSF, Yu WY, Tam PKH, Che CM and Lin CLS. Int. J. Cancer 2009; 124: 19711979.

46. Wang Y, He QY, Sun RWY, Che CM and Chiu JF. Eur. J. Pharmacol. 2007; 554: 113-122. 
47. Chow KHM, Sun RWY, Lam JBB, Li CKL, Xu AM, Ma DL, Abagyan R, Wang Y and Che CM. Cancer Res. 2010; 70: 329-337.

48. Liu JN, Chen H, Li Y, Chen Y, Mao L, Xu A and Wang C. J. Chem. Res. 2011: 698-702.

49. Tanaka K, Mazumder K, Siwu ERO, Nozaki S, Watanabe Y and Fukase K. Tetrahedron Lett. 2012; 53: $1756-1759$.

50. Weishaupt KR, Gomer CJ and Dougherty TJ. Cancer Res. 1976; 36: 2326-2329.

51. Dougherty TJ, Gomer CJ, Henderson BW, Jori G, Kessel D, Korbelik M, Moan J and Peng Q. J. Natl. Cancer Inst. 1998; 90: 889-905.

52. Folkman J. Nat. Med. 1995; 1: 27-31.

53. Fingar VH, Taber SW, Haydon PS, Harrison LT, Kempf SJ and Wieman TJ. In Vivo 2000; 14: 93-100.

54. Huang Z, Chen Q, Luck D, Beckers J, Wilson BC, Trncic N, LaRue SM, Blanc D and Hetzel FW. Lasers Surg. Med. 2005; 36: 390-397.

55. Ichikawa K, Hikita T, Maeda N, Yonezawa S, Takeuchi Y, Asai T, Namba Y and Oku N. Biochim. Biophys. Acta 2005; 1669: 69-74.

56. McMahon KS, Wieman TJ, Moore PH and Fingar VH. Cancer Res. 1994; 54: 5374-5379.

57. Wieman TJ, Mang TS, Fingar VH, Hill TG, Reed MWR, Corey TS, Nguyen VQ and Render ER. Surgery 1988; 104: 512-517.

58. Turcheniuk K, Turcheniuk V, Hage C-H, Dumych T, Bilyy R, Bouckaert J, Héliot L, Zaitsev V, Boukherroub R and Szunerits S. Chem. Commun. 2015; 51: 16365-16368.

59. Rothemund P and Menotti AR. J. Am. Chem. Soc. 1941; 63: 267-327.

60. Lindsey JS, Hsu HC and Schreiman IC. Tetrahedron Lett. 1986; 27: 4969-4970.

61. Lindsey JS, Schreiman IC, Hsu HC, Kearney PC and Marguerettaz AM. J. Org. Chem. 1987; 52: 827-836.

62. Adler AD, Shergali.W and Longo FR. J. Am. Chem. Soc. 1964; 86: 3145-3149.

63. Little RG. J. Heterocycl. Chem. 1981; 18: 129-133.

64. Chouikrat R, Champion A, Vanderesse R, Frochot C and Moussaron A. J. Porphyrins Phthalocyanines 2015; 19: 595600 .

65. Arsenault GP, Bullock E and Macdonald SF. J. Am. Chem. Soc. 1960; 82: 4384-4389.

66. Jain N, Kumar A and Chauhan SMS. Synth. Commun. 2005; 35: 1223-1230.

67. Lucas R, Vergnaud J, Teste K, Zerrouki R, Sol V and Krausz P. Tetrahedron Lett. 2008; 49: 5537-5539.

68. Petit A, Loupy A, Maillard P and Momenteau M. Synth. Commun. 1992; 22: 1137-1142.

69. Boudif A and Momenteau M. Chem. Commun. 1994: 2069-2070.

70. Lee CH, Li FR, Iwamoto K, Dadok J, Bothnerby AA and Lindsey JS. Tetrahedron 1995; 51: 11645-11672.

71. Woodward RB, Ayer WA, Beaton JM, Bickelhaupt F, Bonnett R, Buchschacher P, Closs GL, Dutler H, Hannah J, Hauck FP, Ito S, Langemann A, Legoff E, Leimgruber W, Lwowski W, Sauer J, Valenta Z and Volz H. J. Am. Chem. Soc. $1960 ; 82$ : 3800-3802.

72. Boudif A and Momenteau M. Perkin Trans. 1 1996: 1235-1242.

73. Levy JG. Trends Biotechnol. 1995; 13: 14-18.

74. Sessler JL, Johnson MR and Lynch V. J. Org. Chem. 1987; 52: 4394-4397.

75. Moret F and Reddi E. J. Porphyrins Phthalocyanines 2017; 21: 239-256.

76. Solban N, Rizvi I and Hasan T. Lasers Surg. Med. 2006; 38: 522-531. 
77. Chatterjee DK, Fong LS and Zhang Y. Adv. Drug Del.Rev. 2008; 60: 1627-1637.

78. Piette J, Volanti C, Vantieghem A, Matroule JY, Habraken Y and Agostinis P. Biochem. Pharmacol. 2003; 66: 16511659.

79. Solban N, Ortel B, Pogue B and Hasan T. In Molecualr Imaging: An Essential Tool in Preclinical Research, Diagnostic Imaging, and Therapy, Vol. 49, Bogdanov AA, Licha K. (Eds.), 2005; pp 229-258.

80. Savellano MD and Hasan T. Photochem. Photobiol. 2003; 77: 431-439.

81. Soukos NS, Hamblin MR, Keel S, Fabian RL, Deutsch TF and Hasan T. Cancer Res. 2001; 61: 4490-4496.

82. Bonneau S, Morliere P and Brault D. Biochem. Pharmacol. 2004; 68: 1443-1452.

83. Chung NS and Wasan KM. Adv. Drug Del. Rev. 2004; 56: 1315-1334.

84. Zheng G, Li H, Zhang M, Lund-Katz S, Chance B and Glickson JD. Bioconj. Chem. 2002; 13: $392-396$.

85. Cavanaugh PG. Breast Cancer Res. Treat. 2002; 72: 117-130.

86. Derycke ASL, Kamuhabwa A, Gijsens A, Roskams T, De Vos D, Kasran A, Huwyler J, Missiaen L and de Witte PAM. J. Natl. Cancer Inst. 2004; 96: 1620-1630.

87. Daniels TR, Delgado T, Helguera G and Penichet ML. Clin. Immunol. 2006; 121: 159-176.

88. Cho K, Wang X, Nie S, Chen Z and Shin DM. Clin. Cancer. Res. 2008; 14: 1310-1316.

89. Low PS and Kularatne SA. Curr. Opin. Chem. Biol. 2009; 13: 256-262.

90. Schneider RL, Schmitt F, Frochot C, Fort Y, Lourette N, Guillemin F, Muller JF and Barberi-Heyob M. Biorg. Med. Chem. 2005; 13: 2799-2808.

91. Gravier J, Schneider R, Frochot C, Bastogne T, Schmitt F, Didelon J, Guillemin F and Barberi-Heyob M. J. Med. Chem. 2008; 51: 3867-3877.

92. Zhang M, Zhang ZH, Blessington D, Li H, Busch TM, Madrak V, Miles J, Chance B, Glickson JD and Zheng G. Bioconj. Chem. 2003; 14: 709-714.

93. Di Stasio B, Frochot C, Dumas D, Even P, Zwier J, Muller A, Didelon J, Guillemin F, Viriot ML and Barberi-Heyob M. Eur. J. Med. Chem. 2005; 40: 1111-1122.

94. Frochot C, Di Stasio B, Barberi-Heyob M, Carre MC, Zwier JM, Guillemin F and Viriot ML. Oftalmologia 2003; 56: $62-66$.

95. Lotan R and Raz A. Ann. N. Y. Acad. Sci. 1988; 551: 385-398.

96. Akhlynina TV, Rosenkranz AA, Jans DA and Sobolev AS. Cancer Res. 1995; 55: 1014-1019.

97. Chen B, Pogue BW, Hoopes PJ and Hasan T. Crit. Rev. Eukaryot. Gene Expression 2006; 16: $279-305$.

98. Kamarulzaman EE, Benachour H, Barberi-Heyob M, Frochot C, Wahab HA, Guillemin F and Vanderesse R. In Advances in Cancer Therapy, Gali-Muhtasib. (Ed.) Intech publisher, 2011; pp 99-122.

99. Kamarulzaman EE, Mohd Gazzali A, Acherar S, Frochot C, Barberi Heyob M, Boura C, Chaimbault P, Sibille E, Wahab HA and Vanderesse R. Eur. J. Med. Chem. 2015; 16: 24059-24080.

100. Thomas N, Bechet D, Becuwe P, Tirand L, Vanderesse R, Frochot C, Guillemin F and Barberi-Heyob M. J. Photochem. Photobiol. B: Biol. 2009; 96: 101-108.

101. Thomas N, Pernot M, Vanderesse R, Becuwe P, Kamarulzaman E, Da Silva D, Francois A, Frochot C, Guillemin F and Barberi-Heyob M. Biochem. Pharmacol. 2010; 80: 226-235.

102. Thomas N, Tirand L, Frochot C, Vanderesse R, Guillemin F and Barberi-Heyob M. Photodiagn. Photodyn. Ther. 2008; 5: 92-96 
103. Tirand L, Frochot C, Vanderesse R, Thornas N, Trinquet E, Pinel S, Viriot ML, Guillemin F and Barberi-Heyob M. J. Controlled Release 2006; 111: 153-164.

104. Bhanu K, Komath SS, Maiya BG and Swamy MJ. Curr. Sci. 1997; 73: 598-602.

105. Komath SS, Kenoth R, Giribabu L, Maiya BG and Swamy MJ. Journal of Photochemistry and Photobiology BBiology 2000; 55: 49-55.

106. Kenoth R, Reddy DR, Maiya BG and Swamy MJ. Eur. J. Biochem. 2001; 268: 5541-5549.

107. Sultan NAM, Maiya BG and Swamy MJ. Eur. J. Biochem. 2004; 271: 3274-3282.

108. Kavitha M and Swamy MJ. IUBMB Life 2006; 58: 720-730.

109. Komath SS, Bhanu K, Maiya BG and Swamy MJ. Biosci. Rep. 2000; 20: 265-276.

110. Komath SS, Kavitha M and Swamy MJ. Organic \& Biomolecular Chemistry 2006; 4: 973-988.

111. Goel M, Jain D, Kaur KJ, Kenoth R, Maiya BG, Swamy MJ and Salunke DM. J. Biol. Chem. 2001; 276: $39277-39281$.

112. Goel M, Damai RS, Sethi DK, Kaur KJ, Maiya HG, Swamy MJ and Salunke DM. Biochemistry (Mosc.) 2005; 44: 5588-5596.

113. Goel M, Anuradha P, Kaur KJ, Maiya BG, Swamy MJ and Salunke DM. Acta Cryst. D 2004; 60: $281-288$.

114. de Ruyck J, Roos G, Krammer EM, Prévost M, Lensink MF and Bouckaert J. In Biophysical Techniques in Drug Discovery The Royal Society of Chemistry, 2018; pp 67-86.

115. Rabbani S, Krammer EM, Roos G, Zalewski A, Preston R, Eid S, Zihlmann P, Prevost M, Lensink MF, Thompson A, Ernst B and Bouckaert J. IUCrJ 2017; 4: 7-23.

116. Poiroux G, Pitie M, Culerrier R, Lafont E, Segui B, Van Damme EJ, Peumans WJ, Bernadou J, Levade T, Rouge P, Barre A and Benoist H. PLoS ONE 2011; 6: e23315.

117. Poiroux G, Pitie M, Culerrier R, Segui B, Van Damme EJM, Peumans WJ, Bernadou J, Levade T, Rouge P, Barre A and Benoist H. Photochem. Photobiol. 2011; 87: 370-377.

118. Evangelio E, Poiroux G, Culerrier R, Pratviel G, Van Damme EJM, Peumans WJ, Barre A, Rouge P, Benoist H and Pitie M. Bioconj. Chem. 2011; 22: 1337-1344.

119. Obaid G, Chambrier I, Cook MJ and Russell DA. Angew. Chem. Int. Ed. Engl. 2012; 51: 6158-6162.

120. Obaid G, Chambrier I, Cook MJ and Russell DA. Photochem. Photobiol. Sci. 2015; 14: 737-747.

121. Yu LG, Milton JD, Fernig DG and Rhodes JM. J. Cell. Physiol. 2001; 186: 282-287. 